\title{
Quality of olive oils and olive bagasse oil and their use in thermal processes
}

\author{
Qualidade de azeites e de óleo de bagaço de oliva e seu uso em processos térmicos \\ Calidad de los aceites de oliva y del aceite de orujo de oliva y su uso en procesos térmicos
}

Received: 01/16/2021 | Reviewed: 01/19/2021 | Accept: 01/26/2021 | Published: 02/02/2021

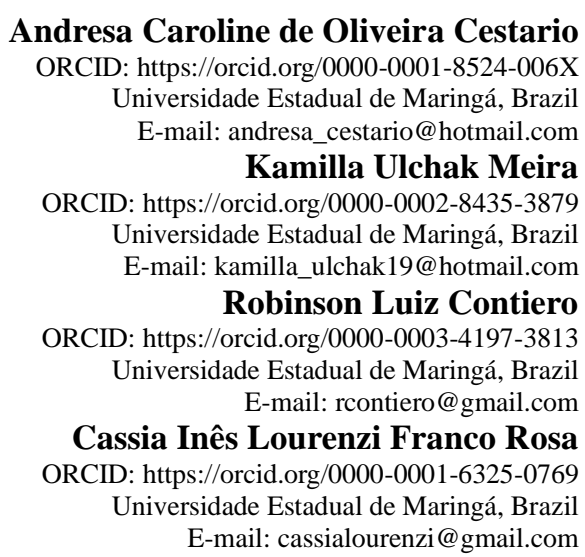

\begin{abstract}
Olive oil is recognized due to its different properties, however, its most used form is in cold preparation, as there is still the belief that, once heated, olive oil would lose its beneficial properties to health and even form toxic substances. Thus, in order to assess the quality of olive oils and olive bagasse oil subjected to different temperatures and their use in thermal processes, the present study was developed at the Laboratory of Medicinal Plants, belonging to the State University's Department of Agronomy of Maringá. The following analyzes were performed when the oils reached temperatures of 10,25 (room temperature), $140,180,220$ and $260^{\circ} \mathrm{C}$ : acidity, peroxide index, iodine index and measurement of absorbance at 232 and $270 \mathrm{~nm}$ (ultraviolet). After the results obtained are compared with the standards of Codex Alimentarius, the Agência Nacional de Vigilância Sanitária, the Ministério da Agricultura, Pecuária e Abastecimento and the International Olive Council, it is concluded that even after heating, in most of the evaluated parameters, the oils remained in compliance with legislation, which can then be used in thermal processes.

Keywords: Health; Heating; Legislation; Olive tree; Properties; Standard.
\end{abstract}

\section{Resumo}

O azeite de oliva é reconhecido devido às suas diversas propriedades, contudo, sua forma mais utilizada é na preparação fria, pois ainda existe a crença de que, uma vez aquecido, o azeite de oliva perderia suas propriedades benéficas à saúde e até mesmo formaria substâncias tóxicas. Dessa forma, visando avaliar a qualidade de azeites e do óleo de bagaço de oliva submetidos a distintas temperaturas e o uso dos mesmos em processos térmicos, desenvolveuse o presente trabalho, no Laboratório de Plantas Medicinais, pertencente ao Departamento de Agronomia da Universidade Estadual de Maringá. As seguintes análises foram realizadas quando os azeites atingiram temperaturas de $10^{\circ} \mathrm{C}, 25^{\circ} \mathrm{C}$ (temperatura ambiente), $140^{\circ} \mathrm{C}, 180^{\circ} \mathrm{C}, 220^{\circ} \mathrm{C}$ e $260^{\circ} \mathrm{C}$ : acidez, índice de peróxidos, índice de iodo e absorbância no ultravioleta a 232 e $270 \mathrm{~nm}$. Após os resultados obtidos serem comparados com os padrões do Codex Alimentarius, da Agência Nacional de Vigilância Sanitária, do Ministério da Agricultura, Pecuária e Abastecimento e do International Olive Council, conclui-se que mesmo após aquecidos, na maioria dos parâmetros avaliados, os azeites e o óleo de bagaço de oliva permaneceram em conformidade com as legislações, podendo então os mesmos serem utilizados em processos térmicos.

Palavras-chave: Aquecimento; Legislação; Oliveira; Padrão; Propriedades; Saúde.

\section{Resumen}

El aceite de oliva es reconocido por sus diversas propiedades, sin embargo, su forma más utilizada es en preparación en frío, ya que aún se cree que, una vez calentado, el aceite de oliva perdería sus propiedades beneficiosas para la salud e incluso formaría sustancias toxicas. Así, con el fin de evaluar la calidad de los aceites de oliva y aceite de orujo de oliva sometidos a diferentes temperaturas y su uso en procesos térmicos, el presente trabajo se desarrolló en el Laboratorio de Plantas Medicinales, perteneciente al Departamento de Agronomía de la Universidad Estatal de Maringá. Se realizaron los siguientes análisis cuando los aceites alcanzaron temperaturas de $10^{\circ} \mathrm{C}, 25^{\circ} \mathrm{C}$ (temperatura ambiente), $140^{\circ} \mathrm{C}, 180^{\circ} \mathrm{C}, 220^{\circ} \mathrm{C}$ y $260^{\circ} \mathrm{C}$ : acidez, índice de peróxido, índice de yodo y absorbancia en el ultravioleta 
a 232 y $270 \mathrm{~nm}$. Luego de comparar los resultados obtenidos con los estándares del Codex Alimentarius, la Agência Nacional de Vigilância Sanitária, el Ministério da Agricultura, Pecuária e Abastecimento y el International Olive Council, se concluye que incluso después de calentar, en la mayoría de los parámetros evaluados, los aceites y el aceite de orujo de oliva se mantuvo en cumplimiento de la legislación, que luego se puede utilizar en procesos térmicos.

Palabras clave: Calefacción; Legislación; Aceitunera; Patrón; Propiedades; Salud.

\section{Introduction}

The olive tree (Olea europaea L.) is a plant originating in the Mediterranean Basin, which around 1820 was introduced in Brazil by European immigrants (Castro et al., 1997 as cited in Cardoso, 2006, p. 3). Its fruit, the olives, is used for consumption in the form of preserves and for the extraction of olive oil, presenting the following composition when fresh: water (40-45\%), carbohydrates (10-20\%) and lipids (30\% of ripe fruit, being 50\% found in the pericarp) (Bruneton, 2001).

According to National Health Surveillance Agency (ANVISA) (Ministério da saúde, 2005), olive oils obtained from the olive tree are classified in three ways: olive oil, which is obtained only from the fruits of the olive tree, excluding any mixture of other oils and oils obtained by solvents or re-esterification processes; virgin olive oil, obtained from the fruit of the olive tree submitted only to the washing, decanting, centrifugation and filtration treatments, passing only through mechanical or physical processes, under thermal conditions, which do not produce changes in the oil and, finally, the refined olive bagasse oil, which is the product obtained from olive fruit bagasse with physical treatments or with solvents, the product must be refined, excluding oils obtained by re-esterification or any mixture of other oils.

Several studies have shown evidence that the amount of phenolic compounds together with a higher proportion of monounsaturated fats (oleic acid), as in the case of olive oil, is positively related to health, making it valuable and appreciated in the diet. Among its health benefits, we can highlight the reduction of risk factors for heart disease, the prevention of cancer and the modification of immune and inflammatory responses (Bendini et al., 2007).

Even though Brazil is positioned among the ten largest world consumers of olive oil, our consumption per capita is still very low, around 0,365 kg/year. Comparatively, in European Union consumption is 3,11 kg/year, in United States is 0,960 $\mathrm{kg} / \mathrm{year}$ and in Turkey $2,15 \mathrm{~kg} / \mathrm{year}$ of oil is consumed, being the three largest world consumers, respectively (International Olive Council [COI], 2019).

One of the possible reasons for this low consumption refers to the combination of the high price, when compared to other vegetable oils, and the idea that its use should be restricted to the finalization of culinary dishes, that is, in cold form. Many are also unaware of the health benefits of olive oil, thus giving little importance to this food. In fact, there is still a belief that, once heated, olive oil would lose its beneficial properties to health and even form toxic substances (Dutra et al., 2013).

Rancidity, or deterioration of fat, can occur through oxidative or hydrolytic rancidity. Oxidative rancidity is caused by the auto-oxidation of triacylglycerols with unsaturated fatty acids by atmospheric oxygen which, in foods rich in lipids, is the main responsible for the deterioration, resulting in undesirable changes in color, flavor, aroma and consistency of the food (Wankenne, 2014). For Ziller (1996), the oxidation rate is accelerated as the temperature increases, and the oxidative reactions in these cases will not follow the same routes and mechanisms as those produced at room temperature.

Hydrolytic rancidity is caused by the hydrolysis of the ester bond by lipase or chemical agent in the presence of moisture (Wankenne, 2014). According to Andrade (2006), it is characterized by the breaking of triglycerides with the consequent release of fatty acids. This process can be caused by microorganisms or enzymes present in food. Under heat action, the reaction is favored, and can lead to the dehydration of glycerol forming acrolein (2-propenal). For Bobbio and Bobbio (2003), acrolein is a compound with an unpleasant smell and irritating for the eyes, mucous membranes and skin. 
Coni et al. (2004), in oil oxidation studies using thermo-gravimetric tests, related to olive oil subjected to thermal process $\left(70\right.$ and $\left.160^{\circ} \mathrm{C}\right)$, verified that, although oxidation occurs, a resistance to this phenomenon was also observed, and in this phase, losses of water and volatile compounds were predominantly; however, above that temperature the oxidation rates increase rapidly.

In this way, the present study had as objective to evaluate the quality of the olive oils and olive bagasse oil subjected to different heating temperatures. The results obtained were compared with the standards of Codex Alimentarius, the Ministério da Agricultura, Pecuária e Abastecimento (MAPA), Ministério da Saúde and the International Olive Council (COI).

\section{Methodology}

The present experiment was carried out in January 2018, at the Laboratory of Medicinal Plants, belonging to the Department of Agronomy of the State University of Maringá. For the evaluation, four types of olive oils were purchased at local market: "extra virgin olive oil"; "olive oil"; "Gourmet vegetable oil" (olive bagasse oil) and "vegetable oil" (soy oil; the most used in thermal processes and used as a control). Each type of oil was subjected to six different temperatures, corresponding to the treatments carried out: $\mathrm{T} 1-10^{\circ} \mathrm{C}\left(24\right.$ hours in BOD), $\mathrm{T} 2-25^{\circ} \mathrm{C}$ (room temperature), $\mathrm{T} 3-140^{\circ} \mathrm{C}, \mathrm{T} 4-$ $180^{\circ} \mathrm{C}$, T5 $-220^{\circ} \mathrm{C}$ and $\mathrm{T} 6-260^{\circ} \mathrm{C}$. For each treatment, five repetitions were performed.

For treatments $3,4,5$ and 6 , the samples were heated to the corresponding temperatures, monitored with a digital thermometer, and then stored in amber glass bottles. For T1, the samples were stored and remained for 24 hours in B.O.D., and for $\mathrm{T} 2$ the samples were only stored.

According to Pereira et al. (2018), a research was carried out using a quantitative and experimental methodology on the quality of olive oils and olive bagasse oil when it subjected a thermal process. The analyzes were performed according to the methods described by the Adolfo Lutz Institute (2008): acidity (this index can be defined as the number of mg of potassium hydroxide needed to neutralize one gram of the sample, providing an important data to evaluating conservation status of oils); peroxide index (which determines all substances, in terms of milliequivalents of peroxide per $1 \mathrm{~kg}$ of sample, which oxidize potassium iodide under test conditions); iodine index by the Wijs method (the iodine index of an oil is a measure of its degree of unsaturation and is expressed in terms of the number of centigrams of iodine absorbed per gram of the sample $(\%$ iodine absorbed)); and specific extinction by absorption in the ultraviolet region at $232 \mathrm{~nm}$ and $270 \mathrm{~nm}$ (this analysis provides information on the quality of an oil, its state of conservation and changes caused by processing, being expressed as specific extinction for absorption of a $1 \%$ solution of unspecified oil, in a thickness of $1 \mathrm{~cm}$, conventionally indicated by $\mathrm{K}$ (extinction coefficient). 


\section{Results and Discussion}

Tables 1 and 2 show the results obtained in the analyzes carried out on the different types of oils.

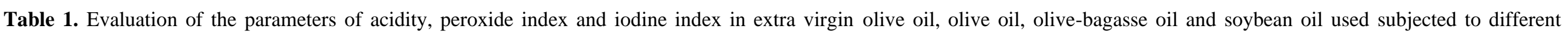
temperatures.

\begin{tabular}{|c|c|c|c|c|c|c|c|c|c|c|c|c|}
\hline \multirow[t]{2}{*}{ Temperature $\left({ }^{\circ} \mathrm{C}\right)$} & \multicolumn{4}{|c|}{ Acidity ( \% oleic acid) } & \multicolumn{4}{|c|}{ Peroxide Index (mEq / kg) } & \multicolumn{4}{|c|}{ Iodine Index (Wijs) } \\
\hline & EVOL* & OO & OBO & SO & EVOL* & OO & OBO & SO & EVOL* & OO & OBO & SO \\
\hline 10 & $0,47 \mathrm{a}$ & $0,51 \mathrm{a}$ & $0,28 \mathrm{~b}$ & $0,18 \mathrm{a}$ & $3,84 \mathrm{c}$ & $7,49 \mathrm{~b}$ & $4,13 \mathrm{c}$ & $1,11 \mathrm{a}$ & $73,40 \mathrm{a}$ & $73,56 \mathrm{a}$ & $65,38 \mathrm{a}$ & $125,58 \mathrm{a}$ \\
\hline 25 & $0,43 \mathrm{a}$ & $0,46 \mathrm{~b}$ & $0,28 \mathrm{~b}$ & $0,19 \mathrm{a}$ & $4,19 \mathrm{~b}$ & $3,07 \mathrm{~d}$ & $3,38 \mathrm{~d}$ & $2,08 \mathrm{a}$ & $70,60 \mathrm{a}$ & $70,60 \mathrm{a}$ & 71,99 a & $123,12 \mathrm{a}$ \\
\hline 140 & $0,45 \mathrm{a}$ & $0,45 \mathrm{~b}$ & $0,29 \mathrm{~b}$ & $0,17 \mathrm{a}$ & $4,98 \mathrm{a}$ & $3,55 \mathrm{~d}$ & $4,65 \mathrm{c}$ & $1,47 \mathrm{a}$ & $72,75 \mathrm{a}$ & $73,76 \mathrm{a}$ & $69,30 \mathrm{a}$ & $125,09 \mathrm{a}$ \\
\hline 180 & $0,42 \mathrm{a}$ & $0,44 \mathrm{~b}$ & $0,29 \mathrm{~b}$ & $0,18 \mathrm{a}$ & $4,50 \mathrm{~b}$ & $5,07 \mathrm{c}$ & $6,78 \mathrm{~b}$ & $2,83 \mathrm{a}$ & $75,21 \mathrm{a}$ & $69,92 \mathrm{a}$ & $69,14 \mathrm{a}$ & 123,97 a \\
\hline 220 & $0,38 \mathrm{~b}$ & $0,44 \mathrm{~b}$ & $0,29 \mathrm{~b}$ & $0,17 \mathrm{a}$ & $3,27 \mathrm{c}$ & $7,54 \mathrm{~b}$ & $7,93 \mathrm{a}$ & $2,27 \mathrm{a}$ & $70,86 \mathrm{a}$ & $67,57 \mathrm{~b}$ & $70,35 \mathrm{a}$ & $122,95 \mathrm{a}$ \\
\hline 260 & $0,36 \mathrm{~b}$ & $0,37 \mathrm{c}$ & $0,31 \mathrm{a}$ & $0,18 \mathrm{a}$ & $3,74 \mathrm{c}$ & $10,57 \mathrm{a}$ & $7,77 \mathrm{a}$ & $3,08 \mathrm{a}$ & $73,33 \mathrm{a}$ & $65,06 \mathrm{~b}$ & $68,30 \mathrm{a}$ & $124,34 \mathrm{a}$ \\
\hline C.V. (\%) & 9,90 & 3,62 & 3,11 & 7,96 & 10,47 & 15,68 & 7,62 & 64,83 & 7,31 & 4,97 & 6,42 & 7,34 \\
\hline
\end{tabular}

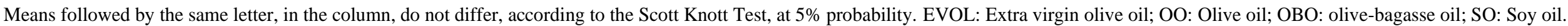
Source: Authors.

In Table 1, we can observe the acidity parameter, which is related to hydrolytic processes, where the results show a high quality of the tested olive oils; the peroxide index,

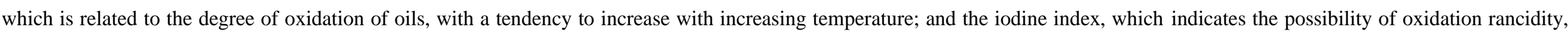
where olive oil in both treatments with higher temperatures showed less susceptibility to this type of rancidity. 
Research, Society and Development, v. 10, n. 2, e2310212031, 2021

(CC BY 4.0) | ISSN 2525-3409 | DOI: http://dx.doi.org/10.33448/rsd-v10i2.12031

Table 2. Evaluation of the specific extinction parameter in extra virgin olive oil, olive oil, olive-bagasse oil and soybean oil submitted to different temperatures.

\begin{tabular}{|c|c|c|c|c|c|c|c|c|}
\hline \multirow[t]{2}{*}{ Temperature $\left({ }^{\circ} \mathrm{C}\right)$} & \multicolumn{4}{|c|}{ Specific Extinction (232 nm) } & \multicolumn{4}{|c|}{ Specific Extinction $(270$ nm) } \\
\hline & EVOL* & OO & OBO & SO & EVOL* & OO & OBO & SO \\
\hline 10 & $1,78 \mathrm{c}$ & $2,00 \mathrm{c}$ & $2,32 \mathrm{~b}$ & $2,51 \mathrm{a}$ & $0,21 \mathrm{~d}$ & $0,48 \mathrm{~d}$ & $1,16 \mathrm{~d}$ & $2,26 \mathrm{a}$ \\
\hline 25 & $1,75 \mathrm{c}$ & $2,02 \mathrm{c}$ & $2,34 \mathrm{~b}$ & $2,39 \mathrm{a}$ & $0,19 \mathrm{c}$ & $0,48 \mathrm{~d}$ & $1,18 \mathrm{~d}$ & $2,23 \mathrm{a}$ \\
\hline 140 & $1,76 \mathrm{c}$ & $2,01 \mathrm{c}$ & $2,39 \mathrm{a}$ & $2,34 \mathrm{a}$ & $0,22 \mathrm{~d}$ & $0,48 \mathrm{~d}$ & $1,22 \mathrm{~d}$ & $2,22 \mathrm{a}$ \\
\hline 180 & $1,77 \mathrm{c}$ & $2,05 \mathrm{c}$ & $2,42 \mathrm{a}$ & $2,44 \mathrm{a}$ & $0,47 \mathrm{c}$ & $0,78 \mathrm{c}$ & $1,33 \mathrm{c}$ & $2,28 \mathrm{a}$ \\
\hline 220 & $1,94 \mathrm{~b}$ & $2,11 \mathrm{~b}$ & $2,36 \mathrm{~b}$ & $2,63 \mathrm{a}$ & $0,69 \mathrm{~b}$ & $0,93 \mathrm{~b}$ & $1,55 \mathrm{~b}$ & $2,34 \mathrm{a}$ \\
\hline 260 & $2,23 \mathrm{a}$ & $2,20 \mathrm{a}$ & $2,38 \mathrm{a}$ & $2,71 \mathrm{a}$ & $0,89 \mathrm{a}$ & $1,20 \mathrm{a}$ & $1,93 \mathrm{a}$ & $2,30 \mathrm{a}$ \\
\hline C.V. (\%) & 3,67 & 1,44 & 1,10 & 14,40 & 9,37 & 6,94 & 3,52 & 5,48 \\
\hline
\end{tabular}

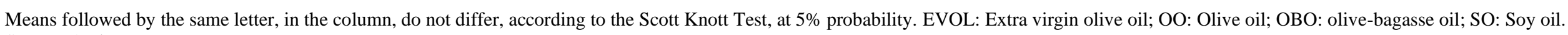
Source: Authors. 
Table 2 shows the coefficients K232, which refers to primary oxidation products, and K270, which is influenced by primary and secondary oxidation products, where there is an increase in primary and secondary oxidation products during the heating process.

Through the results obtained, it can be seen that for the acidity, extra virgin olive oil, had lower values at the two highest temperatures, for olive oil, the value was higher at $10^{\circ} \mathrm{C}$ and lower at $260^{\circ} \mathrm{C}$, this may be related to the high quality of these oils. Malheiro et al. (2009) also verified in studies with virgin and extra virgin olive oils, that even after heating, there were no significant changes in the acidity index, possibly due to the low occurrence of hydrolytic enzymes that are usually present in the fruit of the olive tree or in microorganisms. In olive bagasse oil, only the treatment with the highest temperature differed from the others, showing an increase in acidity, possibly due to its lower quality when compared to olive oils.

In an oil quality analysis, the acidity parameter becomes necessary due to its relationship with hydrolytic processes. The hydrolysis reaction triggered by humidity and temperature, leads to the production of diacylglycerols and free fatty acids from triacylglycerols. The diacylglycerols that are formed can also be hydrolyzed to monoacylglycerols, these to glycerol and free fatty acids, being the increase in acidity the main consequence of this reaction (Katragadda et al., 2010).

According to the legislation proposed by the agencies that regulate the quality standards of olive oils and oils, for extra virgin olive oil the acidity index must be less than or equal to $0.8 \mathrm{~g} / 100 \mathrm{~g}$ in oleic acid, for olive oils and olive bagasse oils, less than or equal to $1.0 \mathrm{~g} / 100 \mathrm{~g}$ of oleic acid. For soybean oil, this value must be less than or equal to $0.20 \mathrm{mgKOH} / \mathrm{g}$. Therefore, even after the samples were heated, they remained within the allowed limits of acidity (Ministério da Agricultura, Pecuária e abastecimento [MAPA], 2006; Ministério da Agricultura, Pecuária e abastecimento [MAPA], 2012; Ministério da Saúde, 2005; Codex Alimentarius, 2017; International Olive Council [COI], 2011).

Extra virgin olive oil, olive oil and olive bagasse oil appeared again, even after heating, within the limits established for the peroxide index parameter, these being less than or equal to 20,15 and $15 \mathrm{mEq}$ of peroxide per $\mathrm{kg}$ of sample, respectively. Soy oil, on the other hand, when heated to 180 and $260^{\circ} \mathrm{C}$ showed a value slightly above $2.5 \mathrm{mEq} / \mathrm{kg}$, a limit described by one of the legislations (MAPA, 2006; MAPA, 2012; Ministério da Saúde, 2005; Codex Alimentarius, 2017; COI, 2011).

The peroxide index is related to the degree of oxidation of oils and fats resulting from the action of oxygen, being potentiated by the increase in temperature, as observed for olive oil and olive bagasse oil, where the amount of peroxides was higher in the treatment with higher temperature for olive oil and it was also higher at 220 and $260{ }^{\circ} \mathrm{C}$ for olive bagasse oil. On the other hand, for extra virgin olive oil the peroxide index initially increased and when subjected to higher temperatures it decreased, according to what was observed by Malheiro et al. (2009), since there is an increase in the oxidation speed due to the high temperature, and then the conjugated hydroperoxides decompose into secondary oxidation products (Karakaya \& Simsek, 2011).

The iodine index is based on the fact that in fatty acids, iodine and other halogens are added to the double bond of the unsaturated chain. Greater unsaturation results in a higher iodine index, thus increasing the possibility of oxidation rancidity (Cecchi, 2003). For this parameter, only olive oil showed a significant difference between treatments, being lower in the two treatments with higher temperatures, demonstrating in these conditions, less susceptibility to this type of rancidity. All olive oils and oils used in this study, even at room temperature, were below the value established for this index, being 75-94 for extra virgin olive oil and olive oil, 75-92 for olive bagasse oil and 124-139 for soybean oil (MAPA, 2006; MAPA, 2012; Codex Alimentarius, 2017).

The K232 coefficient refers to primary oxidation products, while the K270 coefficient is influenced by both conjugated triennials (primary products) and secondary oxidation products (Frankel, 1998). High extinction coefficients in the ultraviolet region indicate oxidation or unfolding of products formed during the storage period of olive oil, or due to chang es in 
refining, demonstrating the presence of olive oil or refined oil in the analyzed sample (Aguilera et al., 2005; Boskou, 1998). Thus, low values of these specific coefficients, indicate the good quality of an olive oil (Aparicio \& Harwood, 2003).

In the specific extinction at $232 \mathrm{~nm}$, for extra virgin olive oil and olive oil, it is noted that after $180^{\circ} \mathrm{C}$ the values increased gradually with increasing temperature, indicating the occurrence of primary oxidation in oils when heated at 220 and $260^{\circ} \mathrm{C}$. For olive bagasse oil, the highest values were found under temperatures of 140,180 and $260^{\circ} \mathrm{C}$. As for the specific extinction at $270 \mathrm{~nm}$, with the exception of soybean oil, from $140^{\circ} \mathrm{C}$ the others showed increasing values as the temperature increased, corresponding to an increase in primary and secondary oxidation products during the heating process. Bešter et al. (2008) working with the heating of extra virgin olive oils, also observed an increase in the values of K232 and K270 during the heating of the olive oils.

Only for extra virgin olive oil, the legislation determines a maximum value for the K232 coefficient, which is less than or equal to 2.50 , so in this parameter even after heating the samples remained in compliance with the legislation. However, for the K270 coefficient, for extra virgin olive oil the limit of 0.22 has been exceeded in the last three treatments with the highest temperatures. Similarly, when heated in the last two highest temperatures, olive oil also exceeded the limit, less than or equal to 0.90 established. With the value of 1.70 as a limit for the K270 coefficient, only when heating with the highest temperature the olive bagasse oil presented values above to the defined by legislation (MAPA, 2012; Codex Alimentarius, 2017; COI, 2011).

According to Philippi (2014), the smoke point is a physical change that occurs when oils and fats are heated to high temperatures, at this point, the glycerol is dehydrated, giving rise to acrolein, a volatile and irritating substance in the gastric mucosa, and the emission of white and dense smoke can be observed during this hydrolysis. Olive oil reaches its smoke point between $175-180^{\circ} \mathrm{C}$, while soybean oil reaches $240^{\circ} \mathrm{C}$, thus presenting greater resistance to temperature, being in agreement with what was demonstrated in the results, where no significant difference was observed between treatments, in none of the parameters evaluated for soybean oil.

\section{Conclusion}

In conclusion, for the analyzed parameters, under the proposed heating conditions, olive oils and olive bagasse oil when subjected to high temperatures suffered oxidation. However, of the five parameters analyzed, only for the K270 coefficient they exceeded the standards established by legislation, and olive oils and olive bagasse oil can then be used in thermal processes.

It is suggested for research and future work, studies of the influence of flavoring agents on the physical-chemical characteristics and on the oxidation of extra virgin olive oils, evaluations of the quality of extra virgin olive oil from K-270 specific extinction tests and acidity, and studies on the quality of extra virgin olive oil according to different packaging systems.

\section{References}

Aguilera, M. P., Beltrán, G., Ortega, D., Fernandéz, A., Jiménez, A., \& Uceda, M. (2005). Characterization of virgin olive oil of Italian olive cultivars: Frantoio and Leccino, grown in Andaluzia. Food Chemistry, 89(3), 387-391. https://doi.org/10.1016/j.foodchem.2004.02.046

Andrade, E. C. B. (2006). Análise de alimentos: Uma visão química da nutrição. Livraria Varela.

Aparicio, R., \& Harwood, J. (2003). Manual del aceite de oliva. Mundi-Prensa.

Bendini, A., Cerretani, L., Carrasco-Pancorbo, A., Gómez-Caravaca, A. M., Segura-Carretero, A., Fernández-Gutiérrez, A., \& Lercker, G. (2007). Phenolic Molecules in Virgin Olive Oils: a Survey of Their Sensory Properties, Health Effects, Antioxidant Activity and Analytical Methods. An Overview of the Last Decade. Molecules, 12(8), 1679-1719. https://doi.org/10.3390/12081679 
Bešter, E., Butinar, B., Bučar-Miklavčič, M., \& Golob, T. (2008). Chemical changes in extra virgin olive oils from Slovenian Istra after thermal treatment. Food Chemistry, 108(2), 446-454. https://doi.org/10.1016/j.foodchem.2007.10.061

Bobbio, F. O., \& Bobbio, P. A. (2003). Introdução à química de alimentos (3a ed.). Livraria Varela.

Boskou, D. (1998). Química y tecnología del aceite de oliva. Mundi-Prensa.

Bruneton, J. (2001). Farmacognosia, fitoquímica, plantas medicinales (2a ed.). Acribia.

Cardoso, L. G. V. (2006). Características físico-químicas e avaliação do perfil de ácidos graxos de azeites obtidos de diferentes variedades de oliveiras introduzidas em Minas Gerais - Brasil [Dissertação de Mestrado, Universidade Federal de Lavras].

Cecchi, H. M. (2003). Fundamentos teóricos e práticos em análises de alimentos (2a ed.). Editora da UNICAMP.

Codex Alimentarius. (2017). Standard for olive oils and olive pomace oils (CODEX STAN 33-1981). http://www.fao.org/fao-who-codexalimentarius/shproxy/en/?lnk=1\&url=https\%253A\%252F\%252Fworkspace.fao.org\%252Fsites\%252Fcodex\%252FStandards\%252FCXS\%2B33-1981\%252FCXS_033e.pdf

Coni, E., Podestá, E., \& Catone, T. (2004). Oxidizability of different vegetables oils evaluated by thermogravimetric analysis. Thermochimica Acta, 418(1-2), 11-15. https://doi.org/10.1016/j.tca.2003.11.038

Dutra, L. B., Duarte, M. S. L., \& Souza, E. C. G. (2013). Tendency of the olive oil consumers profile. Revista do Instituto Adolfo Lutz, 72(4), 322-326. https://docs.bvsalud.org/biblioref/ses-sp/2013/ses-30136/ses-30136-5483.pdf

Frankel, E. N. (1998). Lipid oxidation. The Oily Press.

Instituto Adolfo Lutz. (2008). Métodos físico-químicos para análise de alimentos (4a ed.).

International Olive Council. (2011). Trade standard applying to olive oils and olive-pomace oils (COI/T.15/NC No 3/Rev. 6). http://www.oliva.org.br/wpcontent/uploads/2016/11/olive-oil-standard-coi-6-11-2011.pdf

International Olive Council. (2019). Key-figures on the world market for olive oils. https://www.internationaloliveoil.org/wp-content/uploads/2020/04/110HO-2018.pdf

Karakaya, S., \& Simsek, S. (2011). Changes in Total Polar Compounds, Peroxide Value, Total Phenols and Antioxidant Activity of Various Oils Used in Deep Fat Frying. Journal of the American Oil Chemists' Society, 88(9), 1361-1366. https://doi.org/10.1007/s11746-011-1788-x

Katragadda, H. R., Fullana, A., Sidhu, S., \& Carbonell-Barrachina, Á. A. (2010). Emissions of volatile aldehydes from heated cooking oils. Food Chemistry, 120(1), 59-65. https://doi.org/10.1016/j.foodchem.2009.09.070

Malheiro, R., Oliveira, I., Vilas-Boas, M., Falcão, S., Bento, A., \& Pereira, J. A. (2009). Effect of microwave heating with different exposure times on physical and chemical parameters of olive oil. Food and Chemical Toxicology, 47(1), 92-97. https://doi.org/10.1016/j.fct.2008.10.014

Ministério da Agricultura, Pecuária e abastecimento. (2006). Regulamento Técnico de Identidade e Qualidade dos Óleos Vegetais Refinados; a Amostragem; os Procedimentos Complementares; e o Roteiro de Classificação de Óleos Vegetais Refinados. Ministro de Estado da Agricultura, Pecuária e Abastecimento. http://sistemasweb.agricultura.gov.br/sislegis/action/detalhaAto.do?method=visualizarAtoPortalMapa\&chave=643062246

Ministério da Agricultura, Pecuária e abastecimento. (2012). Regulamento Técnico do Azeite de Oliva e do Óleo de Bagaço de Oliva. Ministro de Estado da Agricultura, Pecuária e Abastecimento. http://sistemasweb.agricultura.gov.br/sislegis/action/detalhaAto.do?method=visualizarAto PortalMapa\&chave $=629707739$

Ministério da Saúde. Agência Nacional de Vigilância Sanitária. (2005). Regulamento técnico para óleos vegetais, gorduras vegetais e creme vegetal. Diretoria Colegiada da Agência Nacional de Vigilância Sanitária. http://bvsms.saude.gov.br/bvs/saudelegis/anvisa/2005/rdc0270_22_09_2005.html

Pereira, A. S., Shitsuka, D. M., Parreira, F. J., \& Shitsuka, R. (2018). Metodologia da pesquisa científica. UFSM, NTE. https://repositorio.ufsm.br/bitstream/handle/1/15824/Lic_Computacao_Metodologia-Pesquisa-Cientifica.pdf?sequence=1

Philippi, S. T. (2014). Nutrição e técnica dietética (3a ed.). Manole.

Wankenne, M. A. (2014). Os tipos e os efeitos da rancidez oxidativa em alimentos. Food Ingredients Brasil, (29), 38-45. https://revistafi.com.br/upload_arquivos/201606/2016060396904001464897555.pdf

Ziller, S. (1996). Grasas y Aceites Alimentarios. Acribia. 